\title{
Industry 4.0 in a dualistic manufacturing sector - qualitative experiences from enterprises and their environment, Eastern Hungary
}

\author{
Csongor NAGY ${ }^{1}$, Ernô MOLNÁR ${ }^{1}$ and Éva KISS ${ }^{2}$
}

\begin{abstract}
Industry 4.0 developing on the basis of digitalisation is gradually transforming production, the conditions of competition and relationships in global industry, affecting its interpretation and expanding its limits. This paper attempts to explore changing economic geographical context with the revaluation of comparative and competitive advantages in a semi-peripheral area of the EU. Based on company interviews, the effects of the new technologies of Industry 4.0 on the dual Hungarian manufacturing industry and its spatial structure are studied, and that whether they contribute to the reduction of duality and geographical polarization. In Eastern Hungary just like in most areas in East-Central Europe - internationally competitive manufacturing companies emerged almost exclusively as a result of foreign direct investment, while domestic companies are forced into secondary or dependent roles. The empirical research has revealed significant differences in the progress of companies in Industry 4.0. Hungarian-owned companies evolve in a specific way from several aspects and face many difficulties. In contrast, enterprises with foreign interest continue to be the engine of development, driven from the "outside". Duality is also reflected in the corporate structure, in space and in the realisation of Industry 4.0.
\end{abstract}

Keywords: Industry 4.0, manufacturing, dualistic economy, enterprises, economic geography, semi-periphery, Hungary.

Received December 2019, Accepted May 2020.

\section{Introduction}

Nowadays the development of industry can be characterized by digitalisation and growing interconnectivity, often referred to as Industry 4.0 (fourth industrial revolution), a name originated from Germany. Changes affecting both the production process and the nature of the products produced have an impact on the structure of value chains and on the applied business models as well. The comparative and competitive advantages of companies and their regions are being revalued, which may lead to the transformation of the spatial organisation and international production networks of the global economy.

The present study focuses on an EastCentral European, semi-peripheral region of the global economy. In an intermediate, dependent area, the income of core-like activities is sufficient to block the forces driving towards peripheralisation, while its low-income (peripheral) activities make it impossible for them to become part of the core (ARrighI, G. 2014). Based on the results of qualitative field research (interviewing) we try to identify some economic geographic relations of the fourth industrial revolution. To this end, the technological preparedness, development and business strategy, resources, knowledge and relationships of the selected companies with the global and local environment were studied. Factors are to be explored that may influence the future prospects and the transformation of the spatial structure of the industry of Eastern Hungary. Considering the dual character of

\footnotetext{
${ }^{1}$ University of Debrecen; H-4032 Debrecen, Egyetem tér 1. Hungary. E-mails: csongormagnus@gmail.com, molnar.erno@science.unideb.hu

${ }^{2}$ Geographical Institute, Research Centre for Astronomy and Earth Sciences; H-1112 Budapest, Budaörsi u. 45;

Faculty of Economics, University of Sopron, H-9400 Sopron, Erzsébet u. 9. Hungary. E-mail: kiss.eva@csfk.mta.hu
} 
the region's economy, the main focus of our analysis will be a comparison between large foreign-owned companies and the Hungarian small and medium-sized enterprises (SME) which have a limited competitiveness.

The study focuses on the manufacturing industry that is expected to have the most pronounced transformation (PorTer, M.E. and Heppelmann, J.E. 2014). From an economic geographical point of view, this sector is also made interesting by its large transnational and multinational companies organised globally and operating spatially fragmented production systems. Manufacturing industry accounts for 80 per cent of the EU's innovation output and 75 per cent of its exports, while its role in the economy of EastCentral Europe is much higher than the EU average (Stehrer, R. and Stöllinger, R. 2015; Lux, G. 2017; NAGY, J. 2017).

In the first part of the study - based on foreign and Hungarian literature - the concept of Industry 4.0 and its potential economic geographical context are analysed, the former Hungarian experiences are discussed and the major specifics of the industry of the studied Eastern Hungarian region are presented. This is followed by a brief description of the research method and by the introduction of the ten enterprises selected. In the third part empirical results are demonstrated from different aspects compared with the conclusions of other researches. The final chapter draws general conclusions and raises further research problems.

\section{Theoretical background}

\section{Industry 4.0 in connection with global economic geography}

The common basis of technologies associated with Industry 4.0 is the development of IT tools with decreasing price and increasing performance, and that of networking and software competences. Similar meanings are associated with the terms of advanced manufacturing, smart manufacturing and Indus- trial Internet of Things (IIoT). Cyber-physical production systems (CPPS) are regarded to be the core elements. For the realisation of CPPS, the devices of our physical world have to be visualized in the virtual world using various technologies (e.g., sensors, radio frequency identification - RIFD, real-time locating system - RTLS). People can be involved in the system through different interfaces, such as a tablet, smartphone or augmented reality (AR). The most important, however, is the large amount of data (Big Data) that is constantly generated in the resulting digital ecosystem that can be handled by cloud computing. With the processing of the above data instant, automatic feedback and realtime decision-making are possible, increasing efficiency and flexibility (BRettel, M. et al. 2014; Monostori, L. et al. 2016; STRANGE, R. and Zucchella, A. 2017; Tortorella, G.L. and FetTERmAnN, D. et al. 2018).

The new technologies are best completed with flexible, easy-to-change production tools such as $\left(3^{\text {rd }}\right.$ generation, autonomous and collaborative) robots and additive (3D) production technologies. The latter is still limited in the manufacture of components with complex geometry, spare parts, prototypes and tools. Modular, networked reconfigurable manufacturing systems (RMS) allow for a degree of flexibility that can make mass customization profitable. In optimising processes, there are also new perspectives in contrast to traditional production systems, as new pathways can be formed at any time, not to mention the possibilities of artificial intelligence (AI) and machine learning. The decision-making process is decentralised and automated, and the product itself can control its production through autonomous devices and machinelevel communication. The role of simulations in process design and product development is significant. Collecting and analysing data can help the planning and automation of procurement, and great progress in maintenance. Individualized traced data represent a major step forward in process development and quality assurance, which can extend to the entire supply chain (BRETTEL, M. et al. 2014; 
Porter, M.E. and Heppelmann, J.E. 2014; RüBMann, M. et al. 2015; Strange, R. and Zucchella, A. 2017; TJahjano, B. et al. 2017).

Digitalisation and Industry 4.0 transform not only production, but also the whole process of value creation, including development, logistics, marketing (e.g. customer involvement) and all (internal and external) relationships. Frequent quasi-continuous development on the basis of flexibility, parallel development of the product and manufacturing process, processing of information collected by smart products and the aftersales opportunities they offer also indicate changes. Integration of the entire value chain enables product lifecycle management (PLM) and could provide basis for circular economy (Brettel, M. et al. 2014; Porter, M.E. and Heppelmann, J.E. 2014; Nagy, J. 2017; RounamaA, H. et al. 2018).

Based on the above, it is clear that Industry 4.0 has certain prerequisites: high degree of automation, network connectivity of devices and their installation with sensors, manufacturing execution system (MES) aimed at the interconnection of processes, collection of real-time information, and control at lower levels, and its connection to IT capacities for the full integration of enterprise processes (e.g., enterprise resource planning - ERP), which enables fast and remote response from management. The new paradigm raises the claim for new standards, whilst interoperability and cybersecurity is essential for networking. The process and directions of standardization is an important element of creating the new balance of power in global industry (at the level of countries and companies), which is clearly going to be dominated by strong actors. New technologies, business models, flows and coordination of value networks, continuous change also require the resolution of a wide range of regulatory and ethical issues (Kagermann, H. et al. 2016; Strange, R. and Zucchella, A. 2017; Nagy, J. 2017; CzÉL, B. 2019).

The development of info-communication technologies enables the increasing coordination of dispersed production, optimisation of the entire value-creating network, foresight and avoidance of disruption for those who influence value chains (AlCÁCER, J. et al. 2016; RounamaA, H. et al. 2018). Further relative increase of the value of enterprise centres is suggested by fixed costs increasing due to the high investment demand of Industry 4.0 and innovativeness and also by variable costs (by units) decreasing due to efficiency (PorTER, M.E. and Heppelmann, J.E. 2014). As a result, the value of production is decreasing even further (Szalavetz, A. 2016). The trend of recent decades has been to deploy production from more developed to less developed countries on a cost basis $(60 \%$ of world trade is intermediate goods) (KIss, E. 2007). If automation becomes cheaper, productivity increases, the proportion of logistics costs (including time) varies and protectionism is strengthened, then the location of production activities close to the consumer can become more attractive, and reshoring will be raised (STRANGE, R. and Zucchella, A. 2017; Laseur, L. 2019).

Closer co-operation with suppliers, the establishment of an ecosystem will be necessary, which will also put innovation pressure on participating companies. Automation of logistics, facilitating identification, using a blockchain mechanism in administration simplifies the flow of products and information in this chain (NAGY, J. 2017). The development of the technologies required for Industry 4.0, the creation of new tools - while ensuring a competitive advantage in the future - can in itself be a remarkable source of revenue, with expected value generation of the background industries providing the new processes amounting to 420 billion euros in 2020 (Monostori, L. et al. 2016). (However, this amount will be probably less because of the COVID-19 pandemic.)

As Industry 4.0 is best developed when more and widespread professions and industries work together, several authors emphasize the importance of the ecosystem approach, the framework of which is gradually established on both national and regional levels (Strange, R. and Zucchella, A. 2017; GöTz, M. and Jankowska, B. 2017; Nick, G. 2018). Digitalisation, which bridges distances 
and the growing importance of local relations, and the apparent contradiction between agglomeration trends - in addition to the decreasingly obvious benefits in transaction costs - are explained partly by the demand for face-to-face interaction at competence-creating and the function of the network node and knowledge base of metropolitan spaces (Alcácer, J. et al. 2016). The role of traditional (hard) location choice factors is steadily diminishing and the focus on previous (even suboptimal) location decisions is increasing as the centres of large companies become more embedded. Clusters have similar historical benefits, and as a knowledge environment they can play an essential role in new processes. Local and regional co-operations make easier the flow and spread of knowledge, promotes the development of trust between those involved. The involvement of external resources for each company increases the capacity of innovation, moreover, the expected positive effects are also amplified by proximity (GöTz, M. and JANKowsKA, B. 2017). In particular, for SMEs, a collaborative network is important (BRETTEL, M. et al. 2014). Higher productivity and exports can also be detected in cluster members. Universities can play a central role in innovation co-operation (RouhamaA, H. et al. 2018).

Technological progress is significantly transforming workforce expectations: the role of digital competences, problem solving abilities, creativity or complex thinking is strengthened. It is common for firms to identify the lack of adequately trained workers as one of the main obstacles to exploiting the potential of new processes, particularly in less developed countries. At the same time, some Industry 4.0 solutions are designed to support low-skilled workers (e.g. visualised instructions), therefore expectations may be lowered in certain areas. The role of traditional qualifications is certainly reduced (for welding just like mounting orders are given via a digital interface) while learning and flexibility are increasingly valued (Autor, D.H. 2015; NAGY, J. 2017; Müller, J.M. et al. 2018; Tortorella, G.L. and FettermanN, D. 2018).
New technologies are a risky and expensive investment in the hope of cost reduction and growth, therefore it is important that company leaders realistically see the capabilities of the company (NAGY, J. 2017). The high costs of implementation, the increasingly complex planning and development processes represent increased difficulties for both smaller businesses and companies in periphery areas, and creating the possibilities of financing is critical for SMEs and, particularly for startups (Porter, M.E. and Heppelmann, J.E. 2014; Tortorella, G.L. and Fettermann, D. 2018). For small and medium-sized enterprises the lack of corporate governance competence, strategic thinking and low productivity are restraining forces (Kovács, Sz. et al. 2017; Müller, J.M. et al. 2018). The increasing flow of information between those involved in value chains, international co-operation and supplier contacts create opportunities for a more efficient spill-over of knowledge, technology and know-how, if there is a willingness to receive it. Compared to explicit knowledge, the spread of tacit knowledge is more difficult, and individuals have a key role in the process. However, the positive effects of this phenomenon have not been clearly demonstrated so far, especially when viewed in an aggregated way rather than at the level of individual companies, taking into account those who lost competition (SZANYI, M. 2010; LiU, C.L. and ZHANG, Y. 2014).

\section{The situation in Hungary}

Sporadic experience so far shows that Industry 4.0 innovations are on the rise in Hungary, but in the light of the indices (e.g. DESI, 2019) used for international comparison, the country generally performs modestly (NAGY, J. 2017; NICK, G. 2018; NAGY, Cs. and MolnáR, E. 2019).

The innovations that have been introduced gradually in the companies are designed to address operational challenges (quality, ontime production, flexibility, management of complex manufacturing, labour shortages, increasing productivity), and the openness and 
initiative of local management are also important for the subsidiaries of foreign companies. The role of innovations supporting upgrading can also be demonstrated: certain innovations (modelling, simulation, unified enterprise software) allow for the deployment of outof-production functions, sharing certain tasks with the centre, specialisation for sub-tasks, becoming a competence centre in certain areas relevant to digitalisation. This is proved by the growth of non-manual employment as well. Comparing the situation of subsidiaries and their parent companies, it can be concluded that in the case of the former, development is aimed primarily to improve the efficiency of the manufacturing process (and functional upgrading by integrating more knowledgeintensive activities) while in the case of the latter, innovations related to products or strategic activities (e.g. value chain co-ordination, research and development) dominate (Szalavetz, A. and Somosi, S. 2019).

The employment-reducing effect of technological investments and production returning from Hungary to the parent country are not yet seen. At the same time, more modern capacities elsewhere can be a challenge for the Hungarian economy in the future. However, the gap between parent companies and subsidiaries in terms of value creation is not reduced, there is only a limited increase in local value added (Losonci, D. et al. 2019; Szalavetz, A. 2019). The failure to achieve a paradigm shift in the catch-up model so far appears to support suggestions about the effects of the fourth industrial revolution cementing the established core-periphery structures (LENGYEL, I. et al. 2016).

The spatial effects of Industry 4.0 at subnational level appear little in the focus of analyses. The dual structure of the industry appears to significantly differentiate with Industry 4.0 solutions spreading faster in the motor vehicle and mechanical engineering industry, in foreign-owned companies, in (large) corporations and in those involved in international co-operation, the unequal spatial distribution of which influence also the geography of the acceptance of innovations in Hungary (Nick, G. et al. 2019). Industry 4.0 meanwhile increases the role of locally available competent suppliers in the location selection (Szalavetz, A. and Somosi, S. 2019). From the point of view of spill-over effects, it is promising that NICK, G. (2018) encountered data sharing to their value chain partners in 92 per cent of industry companies in Hungary involved in Industry 4.0.

The role of small and medium-sized enterprises in employment and competitiveness in the post-Fordist economy is significant, their development and Industry 4.0 maturity became an important competitive advantage. In Industry 4.0- at least until much closer cooperation among those involved becomes evident - the larger representatives of the category can have a role, since they can have the resources and organisational background for optimisation feasible due to interconnectivity and have the conditions to supply. The manufacturing industry is over-represented among medium-sized enterprises, however, this sector is still weak in international comparison, even though such companies could have a major role - due to their scattered location - in the development of the gradually emptying rural regions, small and mediumsized towns from economic point of view. The key-obstacles to their competitiveness are: low level of trust, low networking, rare positive examples, inadequacy of the legal system, lack of internationalisation, risk aversion, lack of leadership skills and unresolved financing (Kovács, Sz. et al. 2017).

All the above point to the important role of high-quality deployment factors that can be difficultly reproduced and older industrial areas and potential industrial clusters even at the time of Industry 4.0, therefore it is worth summarising the characteristics of the study area including nine counties (Nógrád, Heves, Borsod-Abaúj-Zemplén, Szabolcs-SzatmárBereg, Hajdú-Bihar, Jász-Nagykun-Szolnok, Békés, Csongrád and Bács-Kiskun) of the country. Eastern Hungary means the eastern half of the country, where the counties mentioned above form three regions (Northern Hungary, Northern Great Plain, Southern Great Plain). 
During the market economy transformation, balancing industrialisation in the state socialist system was replaced by the preferences of foreign private businesses corresponding to an export-oriented modernisation model based on foreign capital resulting in the differentiation of industrial spatial processes (NemEs NAGY, J. and LőcseI, H. 2015). The geographical location of Eastern Hungary, its inherited economic structure and its infrastructure conditions made it a loser of the change. Not only are heavy industrial crisis areas with strong deindustrialisation, but areas in the Great Plain experiencing above average the collapse of eastern markets, the crisis of agriculture and the external dependency of local industry have also gone through a deep recession (KIss, J. 2003), which was at most mitigated by cities with a more stable industry, with a more successful transformation
(Jászberény, Tiszaújváros) or foreign direct investment from the 1990s (Hatvan, Kecskemét) (BArTA, Gy. 2002; Kiss, É. 2010) (Figure 1).

As a result of re-industrialisation after the millennium, the value of certain Eastern Hungarian regions increased and the internal differentiation of these regions could be observed, while the industrial dynamics of Heves and Jász-Nagykun-Szolnok, closer to the capital city, were already significant in the 1990s (BARTA, Gy. et al. 2008), BorsodAbaúj-Zemplén seemingly finishing deindustrialisation and Bács-Kiskun with an increasing value due to the location choice of the automotive industry were classified into the re-industrialising counties only later (LeNGyel, I. et al. 2016; Lengyel, I. and VARGA, A. 2018). County data, however, mask internal spatial disparities: in the re-industrialised

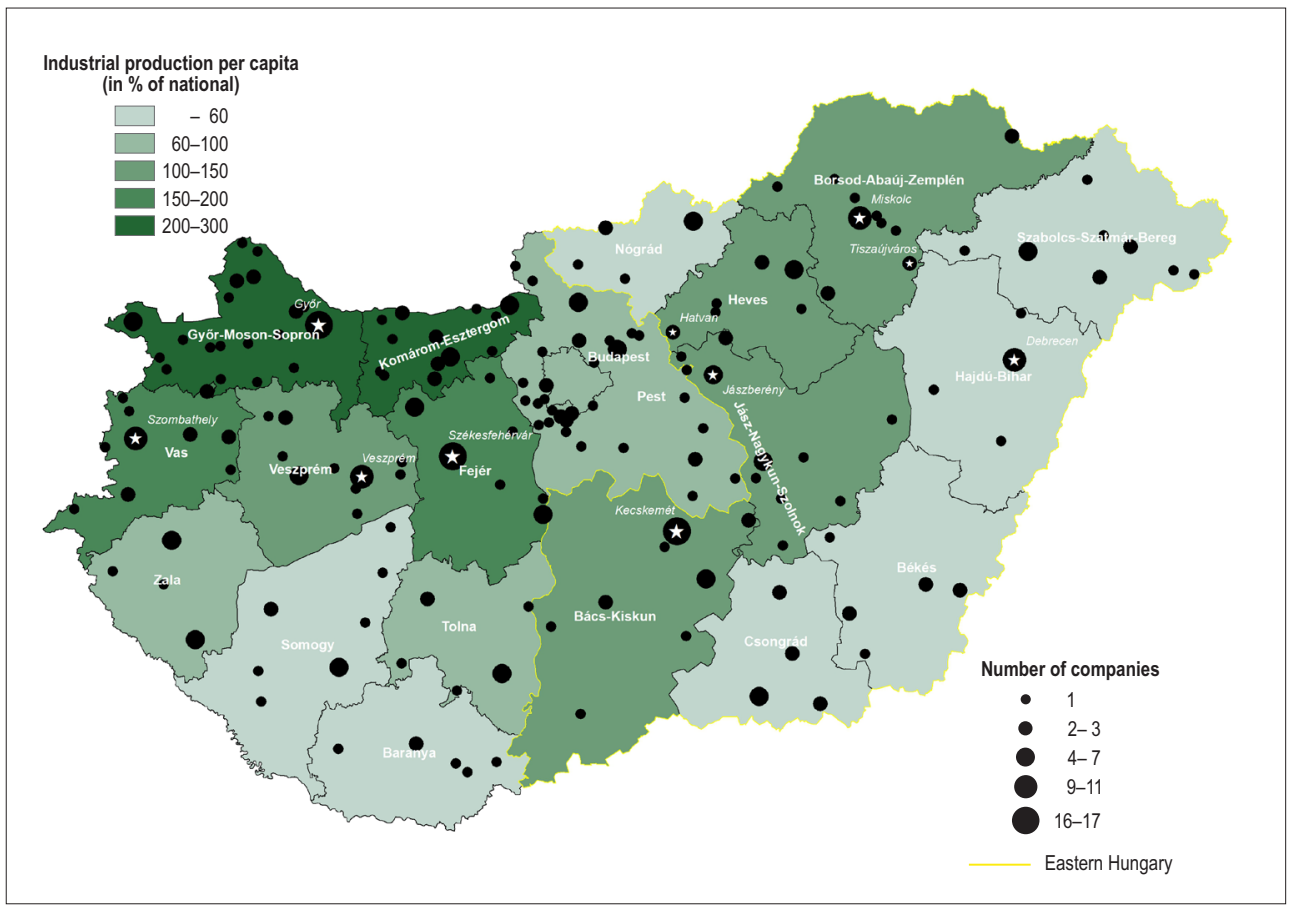

Fig. 1. The value of industrial production per county's inhabitant in per cent of the country's average and the number of manufacturing companies employing at least 250 people by headquarters, 2018. Names of counties (bold) and settlements (italic) with the most manufacturing companies mentioned in the text are labelled by stars. Source: Data of Hungarian Central Statistical Office. 
eastern counties, the axis in the foreground of mountains and the proximity of the capital city seem to be the major factors in determining the spatial structure. This is also reflected in the regional differences of the successfullness of industrial parks (KIss, É. 2013). This shows the resurgence of the north-south differences that have long defined the territorial differences of the Hungarian industry (BARTA, Gr. et al. 2008; KIss, É. 2010), which also suggests the role of inherited conditions in shaping the future (Molnár, E. and LENGYEL, I.M. 2015). Major characteristics of the studied region are demonstrated in a table illustrating well its position within the country (Table 1).

Re-industrialisation also means industrial structural change. With a stronger presence of large foreign companies in more dynamic counties - regardless of geographical location - the dominance of capital-intensive, more value added mechanical engineering (possibly chemical industry) is typical (BARTA, Gy. et al. 2008). In relation to upgrading of Hungary considering factor intensity, the regions that have been re-industrialised later do not start from the same point and seem to be taking similar development paths in less time than their predecessors re-industrialised in the 1990s, as demonstrated by the faster change of activity structures and embedding of some corporations (Józsa, V. 2019). In value chains managed by foreign parent companies, the role of the limited character of functional upgrading in blocking re-industrialised regions and, at the same time, (quality) functions beyond production detectable in the East re-industrialised late fade differences between the old and new industrial areas, e.g. in automotive industry (Molnár, E. et al. 2020).

\section{Methodology and sample}

This research is based on company interviews, designed to collect economic geographically relevant questions related to Industry 4.0 and to outline the possibilities for interpreting correlations in a semi-peripheral economy with dual characteristics. Qualitative methods were applied creating abundant information, flexible conversation, enabling the interviewer to learn continuously and correct the protocol in situ, to reveal causation and to collect information (BABBIE, E. 2008; Liu, C.L. and Zhang, Y. 2014; MüLLER, J.M. et al. 2018).

The semi-structured in-depth interviews were conducted between September and

Table 1. Some data of the industry of Eastern Hungary and Hungary, 2018

\begin{tabular}{l|c|c|c}
\hline \multicolumn{1}{c|}{ Denomination } & $\begin{array}{c}\text { Re-industrialising } \\
\text { counties of Eastern } \\
\text { Hungary* }\end{array}$ & $\begin{array}{c}\text { Other counties of } \\
\text { Eastern Hungary** }\end{array}$ & Hungary \\
\hline $\begin{array}{l}\text { Number of active industrial enterprises } \\
\text { per 1,000 inhabitants }\end{array}$ & 4.7 & 3.8 & 5.1 \\
$\begin{array}{l}\text { Industrial production per inhabitant, } \\
1,000 \text { HUF }\end{array}$ & 4,568 & 1,659 & 3,270 \\
$\begin{array}{l}\text { Industrial employment, number of employees } \\
\text { per 1,000 inhabitants }\end{array}$ & 84 & 59 & 40,889 \\
$\begin{array}{l}\text { Industrial productivity, industrial production } \\
\text { per one industrial employee, 1,000 HUF }\end{array}$ & 54,697 & 28,334 & 4.8 \\
$\begin{array}{l}\text { Number of industrial enterprises employing } \\
\text { at least 250 people per 100,000 inhabitants }\end{array}$ & 4.7 & 10 & 27 \\
$\begin{array}{l}\text { Employment in mechanical engineering, } \\
\text { number of employees per 1,000 inhabitants }\end{array}$ & 34 & 3.5 & \\
\hline
\end{tabular}

*Borsod-Abaúj-Zemplén, Heves, Jász-Nagykun-Szolnok and Bács-Kiskun county (based on Nemes NaGY, J. and LốcseI, H. 2015; Lengyel, I. and VARGA, A. 2018). ** Nógrád, Szabolcs-Szatmár-Bereg, Hajdú-Bihar, Békés and Csongrád county. Source: Data of Hungarian Central Statistical Office. 
December 2019. In line with the exploratory nature of the research, open-ended questions were asked, leaving room for interviewees to interpret them, and gave way to their thoughts depending on the time frame of the conversations (1-3 hours). Like the investigation of Szalavetz, A. and Somosi, S. (2019), what had been said in the conversations was interpreted as a weak signal. In some areas facts were asked, however, opinions regarding certain questions in relation to possible spatial trends were also recorded.

The companies interviewed in Eastern Hungary were selected on the basis of the recommendations of professionals and entrepreneurs who had been visited before. Different industries, region and settlement types are represented in the study, and the size and ownership of the involved companies reflect the dual structure of the economy. Therefore, in the logic of targeted sample selection, the principles of easy accessibility, experts selection, snowball method and quota sampling are mixed (BABBIE, E. 2008). Competent companies are targeted for interviewing in the topic at which some elements or signs of Industry 4.0 have already appeared. Therefore, the sample is not representative of the area's industry.

Composing the question the aim was to obtain experience in practice in relation to the occurrence and possibilities of the fourth industrial revolution in Hungary and to survey the related attitude and strategies of the decision makers. Gathering information on the role of Industry 4.0 in transforming spatial relations, on the assessment of the relevant advantages and disadvantages of the studied region was also important. Naturally, before the interviews available materials (e.g., website, financial reports) were used to obtain information on the companies. After the companies are presented, results are discussed in accordance with the theme of the interview question series, but in a structure with a slightly different logic, reflecting duality and minimising overlaps:

- The occurrence of Industry 4.0 and global economic change at company level are analysed first taking strategy, technology proliferation, process transformation and competencies into account. First, the general trends, then the characteristics of foreign corporations and Hungarian medium-sized enterprises are presented. This is followed by a section where some of the unique characteristics of each company are demonstrated.

- In the second part, locality, the environment, spatiality aspects come to the front, where the role of human resources, suppliers and other relationships is important. Again the analysis follows a route from general trends to the specifics of the two groups of companies (Table 2).

The 10 studied companies include five foreign-owned corporations (subsidiaries) and five Hungarian-owned medium-sized companies located east of the Danube between 80 and 240 kilometres from the capital city. Subsidiaries have long operated at their locations, showing a gradual expansion in terms of size, production and functionality. Stable Hungarian management leads all companies. The beginning of the career of the Hungarian ones can be related to the period of the regime change: they started small and grew gradually, but even today they operate on a family basis.

The gap between multinational corporations and smaller Hungarian businesses was a recurring motif in the discussions (for both types) despite the fact that otherwise respectable innovativeness and competence were experienced at medium-sized enterprises as well. Since experience from both literature and field is consistent with the role of the dual economic structure in space influencing the adaptation of Industry 4.0 innovations, the replies are presented along this policy principle. It is important to emphasize that all interviewees were well-informed about Industry 4.0 and that they were addressing the potential of innovation. At the same time, most of them regard the adaptation of innovations a part of an organic and reasonable development process and - regardless of the upheaval around Industry 4.0 - focus on solving specific problems. 


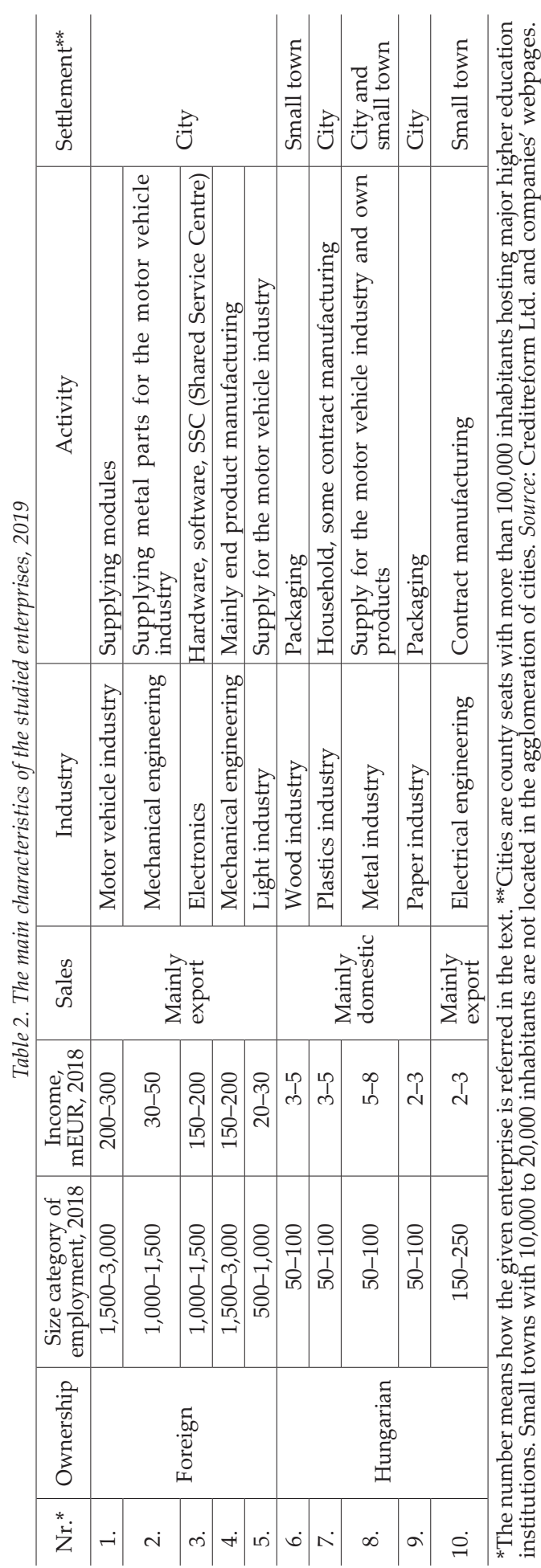

\section{Results of empirical research}

\section{Industry 4.0 at companies}

According to the interviews - similarly to the study of TJAHJono, B. et al. (2017) - the most frequently identified strategic goals regarding the adaptation of Industry 4.0 are productivity growth, efficiency, competitiveness, cost and time optimisation and flexibility. Improvements in labour productivity generate growth for most $(1,2,4,8)$ and the workforce freed up by automation and optimisation is redeployed within the company: technology-based capacity expansion, diversification, headcount-neutral transformation are the goals. Solutions offered by Industry 4.0 are not exclusive and generally not competitive with traditional series production optimised for a single product. Automating with linear-driven target machines is cheaper than robotics, but robots are easier to reuse.

Enterprise resource planning systems considered the foundations of Industry 4.0 are present almost everywhere. The strong influence of the German enterprise culture is also demonstrated by the fact that the SAP system is most widespread (at companies 1, 2, 4, 6). This reflects the management's desire to better understand the processes. Since the modernisation of production infrastructure is not a prerequisite for enterprise resource planning (ERP) systems, only the price of software hinders their spread. However, for its effective operation, it is essential that the necessary information is included as soon as possible, which requires well-organised processes. One corporate leader declared the recipe of Industry 4.0: lean $\rightarrow$ data collection $\rightarrow$ autonomous systems. Principles of lean production representing the demand-driven product organisation logic were mentioned in several companies $(4,5,9)$ in accordance with the results of TORTORELLA, G. L. and Fetterman, D. (2017).

In all cases, the development of corporate Industry 4.0 background competencies was motivated by the relative cheapness and accessibility of own resources, as opposed to the solutions offered by external companies. 
There have also been several cases of worker assistance and improvement of working conditions: on the one hand, the replacement of physically demanding work $(2,6)$ and, on the other hand, reduction of the complexity of tasks in order to create safe operation conditions for both humans and machinery in the form of so called poka-yoke solutions $(4,5)$. Predictive maintenance was mentioned only in two cases $(2,4)$, meanwhile scheduled programs are widespread.

A common speciality of foreign subsidiaries is that they do not make decisions independently. While product development is typically the responsibility of headquarters, production design and sustain engineering are largely subsidiary competences. Due to the dominant production function of the companies, efficiency and cost optimisation are top priority. Hungarian management is more successful due to the lack of cultural and linguistic barriers, providing more leeway, as does the fact if a plant is the sole producer of a product. Local developments are typically generated not by high command, but by keeping the cost level, solving current problems, or the ambitions of local management with limited leeway, as Szalavetz, A. (2016) has experienced.

The technological superiority of subsidiaries is also an important difference. Examples of a working Manufacturing Execution System (MES) and simulation applied in development and lower-level optimisation have only been seen at corporations. 3D printers were used in prototyping $(1,4)$ and indirectly in tool manufacturing (2's supplier). Industry
4.0 provides an opportunity for premises to become a competence centre in certain fields: two automotive suppliers $(1,2)$ for example, in MES, and a third in lean and production support software (5). Two companies have significant robotics and production line building competences for the smooth production $(1,4)$. Product-related services and integration are quite widespread $(1,3,4)$. In terms of quality assurance, increasing traceability stands out (Table 3).

A common feature of Hungarian mediumsized enterprises is that they form a strategy based on several, not only economic, but e.g. individual, family objectives. Ownerexecutives have full decision-making power. In addition to the underdevelopment of organisations, limited resources are the biggest barrier to Industry 4.0 innovations. All managers cited the lack of time in management as an obstacle to development and strategic thinking. There is relevant knowledge in several places, but typically management itself is the intellectual capacity for designing and implementing developments $(6,7,8)$. Many feel that young people, the second generation of corporate governance, are able to break away from their daily routine and deal with strategy and development (MüLLER, J.M. et al. 2018; CzÉL, B. 2019).

All of the asked medium-sized company leaders were concerned about Industry 4.0 in Hungary, while in Czechia 3/4 of the studied companies did not feel Industry 4.0 relevant to them at all, which is of course more the result of targeted selection than the difference between the two countries (Kopr, J. and

Table 3. Some important technologies at the companies interviewed, 2019

\begin{tabular}{l|c|c}
\hline \multicolumn{1}{c|}{ Denomination of technology* } & Foreign corporations & Hungarian medium-sized companies \\
\hline Manufacturing Execution System & $1,2,4,5$ & - \\
Radio Frequency Identification & 1,5 & - \\
Augmented Reality, Virtual Reality & 1 (in education) & - \\
Enterprise Resource Planning & $1,2,3,4,5$ & $6,7,8,9$ \\
Simulation & $1,3,4$ & - \\
Robot & $1,2,4$ & 6,8 \\
3D printer & $1,(2), 4$ & 6 \\
\hline
\end{tabular}

${ }^{*}$ Not all technologies are closely related to Industry 4.0, but they are essential elements. Source: Company interviews, 2019. 
BASL, J. 2017). Trends in the specific cases were rather variable. MES (Manufacturing Execution System) or similar ideas have occurred as future plans in several cases $(7,8$, 9). They are weaker in data collection and processing: efficiency indicators are often not used, however, they want to improve in this field (in accordance with the experience of MüLler, J.M. et al. [2018], and NICK, G. [2018]). The outdated and heterogeneous production infrastructure also often hinders development $(7,8,10)$.

Individual subsidiary examples indicate further practices in the application of Industry 4.0 innovations. Corporation 1 works hard on process innovations besides dynamically changing activities of its manufacturing premises, placing a significant emphasis. According to the manager interviewed, they are gradually moving from low-cost to high-cost location.

Corporation 2 produces low-value products in large quantities, therefore reducing the cost of production and that of material share is particularly important for it. Practicaly all of their machines have been equipped with a monitoring system that enables predictive maintenance and supports quality assurance. They also test robots, which can help in visual inspection during quality control.

Corporation 3 carries out highly diversifiable, high value added (75-80\%), R\&D intensive (nearly 20\%) activities: in addition to hardware manufacturing, software development and system integration takes place and has significant shared service centre (SSC) functions (IT, law, financial service provider, customer service). Nearly half of the employees have diploma. At the same time, their high mix low volume production covers thousands of product variants, which hinders the introduction of the MES. Robots are not considered suitable for fine operations, or to correct minor defects, moreover they receive no support for the modernisation of their production system from the centre.

Corporation 4 also has a high mix low volume product group. To produce this, a special "Industry 4.0 line" has been created that is capable of producing single-piece series, has machine-level interconnectedness, automatically checks the qualification of operators, issues work instructions, has (not visualized) digital twin and provides a oneway material flow in logistics. Deep learning is planned with the help of big data collected with sensors in welding. As a means of limiting the autonomy of the subsidiary, the size of the technical department is limited.

In the case of corporation 5, the barrier to automation is the individuality of the natural raw material, and that of flexible organisation is quality assurance (their safety-sensitive automotive products should only be manufactured using lines designed specifically for the particular product, to be resampled in the event of modifications, approved by car manufacturers). Lean and kaizen approaches dominate in the corporation and it follows self-control and null error strategy. MES works at a low level the corporation uses a less-known, well-customised ERP, however, they are under pressure to switch to SAP.

Individual medium-sized company examples also offer a variety of relevant experiences. The progressive executive of company 6 held back growth and focuses on downsizing developments. It has a robot (and plan to purchase another one) programming of which is carried out by his sons and the robotic arms are 3D-printed. This company was among the first in its size category to purchase a corporate governance system (SAP) in Hungary in order to connect with its customers. This is how it supports delivery scheduling.

Company 7 works primarily with its own product designs. Plastic is difficult to plan and simulate. Due to the tool requirements of injection moulding, the company works with a local supplier, and small series are not profitable. A 3D printer is planned for prototyping. The company also aims to give workers instructions on tablets. In order to track deliveries a mobile app is used and orders are planned to be automated. The company carries out $R \& D$ co-operation with the university of another city.

As the development of the automotive supplier business is costly, company 8 focuses 
more on the own product division. Following the modernisation of the production line (welding robot cell) it plans to expand the related services and integrator functions. For reasons of cost-effectiveness, it developed machinery and ERP together with Hungarian companies; the ERP is well customized to the needs of the firm, however, not sold on the market by the software company. Multiply retrievable data improved their bargaining power and the executive's son has also developed an online price calculator.

Company 9 works with a number of product variants, often small series, on which many operations are carried out. One of the main obstacles to development is that the company cannot change from point production to line production. The ERP of the company is outdated, however, due to high prices no new software has been bought yet. Improvements are supported by a lean engineer.

Company 10 works as a custom manufacturer with small profits that hinders development. Dispersed production on more locations hamper the integration of ERP and the main customer is not partner in interconnection either.

\section{Relationship with the environment of companies}

The spatial effects of Industry 4.0 can be interpreted in two dimensions. On the one hand, it is manifested as the unequal spread of innovations maintaining/re-creating competitiveness (keeping or removing those involved) and, on the other hand, as the effects of the production and value-chain division of labour transformed by Industry 4.0 on spatial relations.

One of the most obvious consequences of Industry 4.0 accompanied with spatial effects is the change in the demand for labour. The role of industrial qualification is diminishing as a result of Industry 4.0, while the need for digital competencies and for the ability to manage complexity is increasing. Some are dissatisfied with the digital competencies of older people (9) and others are dissatisfied with the digital competencies of manual workers (2). Others believe that this is not a problem of the blue-collar workers, but rather important for the white-collar ones (8). Most leaders emphasized the role of education and training within companies. There is a general agreement on the importance of major developments in the education system, often the knowledge of teachers is not adequate. Recruitment becoming hard is felt everywhere, especially in terms of highly qualified workforce. Nevertheless, the region's relative advantage over other parts of the country can be seen. According to the head of the company (8), present in both a city and a town, recruitment is becoming more difficult in both areas, however, it is slightly easier in the small town, which was explained by the workforce released due to the closure of a local foreign company.

In relation to supplier networks critical for the reasons discussed earlier, experts emphasise co-operation with multiple partners (companies, institutions), the flow of information and transparency as the basis for development (TJAhJAno, B. et al. 2017; Müller, J.M. et al. 2018). In our interviews, the role of corporate governance systems has occurred repeatedly $(5,6,10)$, as well as, the Achilles heel of automotive industry supply: quality assurance $(5,7,8)$. The leader of one corporation and that of a medium-sized company set the criteria for fast and flexible communication at a distance of $100 \mathrm{~km}(2,9)$. One corporate leader missed "medium-sized" businesses with hundreds of employees in Hungary (4) who could have the ability to function as stable partners.

R\&D cooperation - regardless whether foreign-owned subsidiary or a Hungarian medium-sized company - occurs only at companies in cities (e.g. machine testing, material science), although it is also planned in small towns $(6,10)$. The availability of tender resources is a general advantage of the region. The positive impact of the development of the main road network on accessibility and flexibility was also mentioned $(6,8)$. The nonoptimal functioning of professional organisations $(4,6,8)$ was raised as a problem. 
The foreign subsidiaries usually have large labour market catchment areas, with one of them having employees from $100 \mathrm{~km}$, across the border (4). In most cases, the share of nonmanual workers $(20-30 \%)$ is much smaller than that of manual workers. The ratio of those with a diploma is not very high. The ratio is generally improving and in some cases this has been linked to Industry 4.0, the expansion of development and IT functions, but this has not always been clear. Where possible, they also make themselves more attractive by remote working or the possibility of home office. In order to have human resources supply, most corporations are actively involved in secondary and higher education, offering dual training. Considering higher education, in addition to technical training $(1,2,4)$, companies are sometimes active in economics (4), however, opinions are divided on whether students should be educated by the companies from the beginning or not. Nevertheless, dual training is an excellent opportunity to attract young talent, i.e. a competitive advantage that requires an accessible (relevant) higher education institute. At secondary school level experiences are generally not very good.

For the foreign subsidiaries, the local supply network offers flexibility, just in sequence organisation, reduced logistical costs and closer co-operation. They themselves are often suppliers therefore the entire chain logically contributes to concentration and spatial specialisation. The supply network is a critical issue for companies with a high material proportion. However, local co-operation is also advisable in the case of tools and services. Most companies $(1,2,4,5)$ strive to improve the local supplier network (mentoring, on-site consultancy, strategic consultations, even joint development), but none of them reported breakthrough successes. They often carry out the task themselves cheaper than a local operator. Some have no Hungarian supplier at all (3), while others talked about Germans in 90 per cent (5) or about suppliers mostly from the Far East (2).

Several multinational corporates appreciated and took advantage of the university and research institute opportunities in their city $(1,2,3,4)$, some reported improved attitudes and conditions in Hungarian institutions that have traditionally not been very open to the market $(2,4)$, others were dissatisfied (3). Co-operation does not necessarily take place with (only) the local institution. They usually take steps to improve their local embedding, and they have good relationship with local political forces. Several corporates trust in the benefits of industrial agglomeration in the field of institutional networking, services and industrial advocacy. Regarding the infrastructure of the location (industrial park), major companies formulated expansion needs at most (4).

Medium-sized companies typically attract no workers from far away and are characterised by a particularly low rate $(<10 \%)$ of workers with a diploma. They seem to accept the fact that they cannot compete for nonmanual workers with multinational corporations. Effective steps are not taken to attract a highly qualified workforce (e.g. teleworking, educational co-operation), the management, the family typically try to solve everything themselves.

In general, there is a low level of cooperation, businesses rely on themselves and government supports, and there is no question of co-operation with competitors. Several companies are involved in the circulation of the global industry as suppliers or custom manufacturers, while they also have suppliers. Several companies consider that the entrepreneurial and supplier culture around the city Győr is more advanced. Pushing down prices and poor bargaining power are the main problems in custom work $(7,10)$. In the life of medium-sized enterprises, personal contacts and soft information play a significant role both towards external businesses (9) and in their internal operation (7). The resulting agility and benefits may become threatened by Industry 4.0. Similar concerns were also raised during the investigation of MüLLER, J.M. et al. (2018).

In the case of Hungarian medium-sized enterprises, the relationship with the local environment is ambivalent. In small towns 
and periphery areas transport management may cause problems $(6,8)$. The role of proximity to the consumer market is indicated by the fact that one of the companies (otherwise in a city) maintains a sales office in Budapest (9). Some did not perceive a constructive attitude from local leaders and businesses (6), others felt that their embedding in the local market was poor (9). Many medium-sized companies $(6,7,8,9,10)$ participate in an Industry 4.0 state programme, in which the Industry 4.0 preparedness of companies is assessed, forerunner factories and training are visited, and finally prepare a development plan. Eventually selected companies will receive customized, professional advice. Such a programme would be truly constructive if development resources were also allocated, therefore grounded decisions customized to individual cases could be made at the time of allocation.

\section{Discussion of empirical experiences}

Based on the Eastern Hungarian experiences it has become obvious that companies are dealing with the Industry 4.0 issue, but the fourth industrial revolution is mostly ahead of us. According to different points of view there are smaller or larger similarities and differences among the companies studied. They are in the different phase of Industry 4.0 (Table 4).

With the transformation of the human resources needs of production adapting Industry 4.0 innovations, it would be logical to consider the reshoring of manufacturing formerly relocated on cost basis to the mainland or near major consumer markets. Relocation of foreign investments is continuous, in Eastern Hungary examples can also be found for activities relocated to or from Hungary, although typically more for the former. Based on automation, however, mass reshoring seems not like. Probably because this

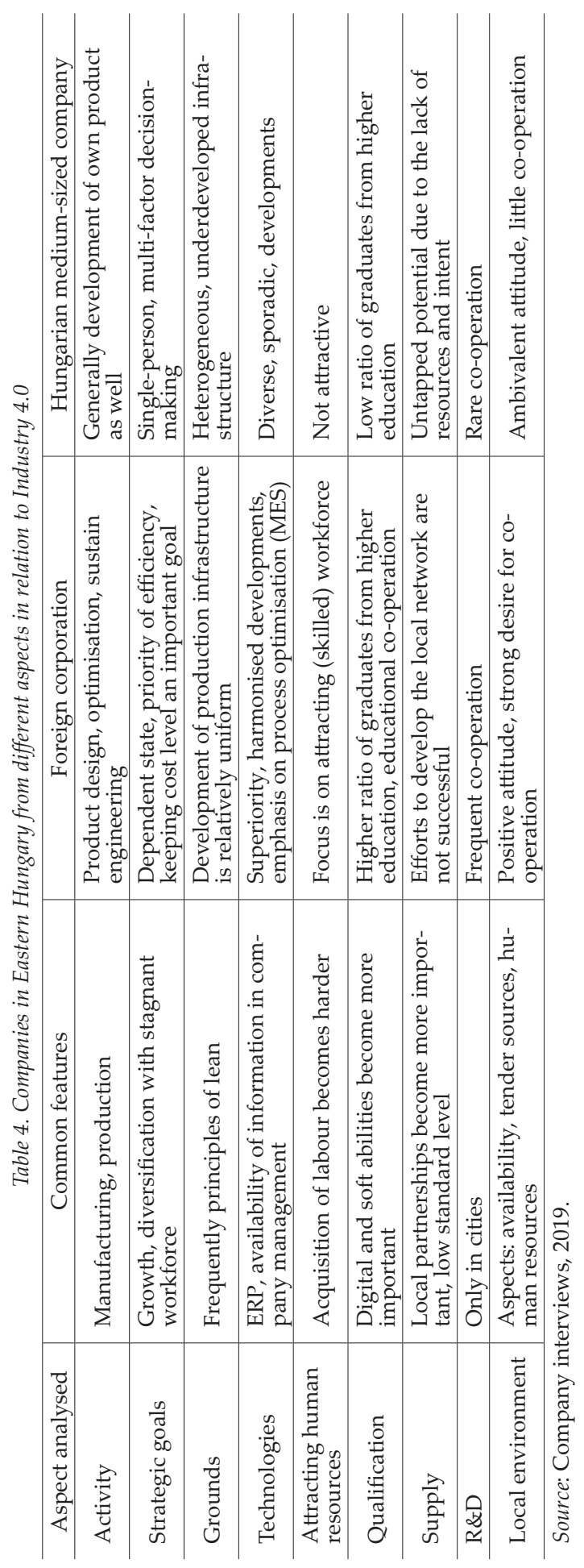


would not be a solution to the socio-economic problems of the parent country, since the lack of highly qualified workforce is the problem there as well, and autonomous production systems require less low and medium-skilled workers. At the same time, considering capacities in the Far East, even a more peripheral region in the EU provides more flexibility as location (nearshoring). The activities of the subsidiaries of multinational corporations diversifying due to the integration of production support, IT and service activities may even prove to be a retaining force.

The opportunities and effects of function expansion due to Industry 4.0 are only partially realised in Hungary, and the changes do not seem to be so remarkable therefore it can be declared that they represent relative progress and upgrading compared to the competitive environment in the world economy. The preparedness of potential suppliers can play an important role in attracting foreign capital. It is also in the interest of Hungarian businesses to be linked to the system with the highest possible level of activity, as this involves greater knowledge transfer (SzANYI, M. 2010). The need for the growing amount and diversity of knowledge not only underlines the importance of education, but also is a guide for its organisation. Education needs to move forward from the previous uniform and static paradigm towards a model aiming for diversity and supporting continuous learning, a basic condition of which is the internal motivation of participants because of flexibility. It is no surprise that the issue of education has concerned almost all of our interviewees.

New technological opportunities give subsidiaries such features (flexibility, efficient information flow, decentralisation, availability, presence) that have previously been the most important competitive advantages of smaller companies. Since there is no effective own organic development model for SMEs at present, it is necessary to create the possibility of financing for learning and development of the smaller ones that can only be achieved through cooperation and ecosystem think- ing (Müller, J.M. et al. 2018; RouhamaA, H. et al. 2018). A competitive advantage could be gained by pooling separate, sporadic developments in a resource-efficient way and eliminating duplication, but this would require a properly functioning network of institutions, an entrepreneurial culture and trust. There is institutional practice for continuous training and for the acquisition of highly qualified professionals at corporations. In contrast, SMEs are not able to cover these needs from their own resources therefore co-operation in this field is also necessary. It is a disadvantage that the employment of highly qualified workers is not emphasized enough at medium-sized enterprises, where the development of the organisational culture is important.

The interviews also confirmed that knowledge and corporate culture essentially spread through people, therefore the support for (Hungarian) smaller companies at system level should be considered by highly qualified employees who possibly obtained experience at multinational corporations. Without the above steps, it is feared that Industry 4.0 will not be a possibility for medium-sized enterprises, but - due to the cumulative, interdependent character of innovations - the inherited disadvantages will be strengthened, further increasing the gap between the competitiveness of corporates and medium-sized companies.

The capital and technology intensity of Industry 4.0, its sector dependence, the central role of multinational corporations, the integration of supply networks, the importance of personal relationships in knowledge generation all point to the fact that the more developed industrial districts or clusters and cities can gain additional benefits. As discussed above, the possibilities of Industry 4.0 can be strongly influenced by the characteristics of manufactured products and raw materials used. This includes two possibilities regarding the development of the spatial structure: on the one hand, areas specialised in industries where the achievements of Industry 4.0 can be applied more easily and thus developed and optimised (the automotive industry seems to be, for the time being, the most dy- 
namic in terms of Industry 4.0 - see MolnáR, E. et al. 2020) and, on the other hand, it may conserve less dynamically developing, labourintensive activities in less developed areas.

In the evolution of the spatial structure of the Hungarian industry, the trends suggest broadly the relative prosperity of the Northern Transdanubia region with a one-sided automotive profile, with a more established relationship system, and that of Budapest and its wider environment with the greatest knowledge and consumer market. In Eastern Hungary, the major cities hosting universities may be mostly the winners of the fourth industrial revolution, while the disadvantage of small towns and rural areas may increase further. It may be encouraging that the respondents considered the suppliers within a 100-200 $\mathrm{km}$ radius to be local, however, nothing indicated that the developments would boost beyond the boundaries of cities and districts.

\section{Conclusions}

The present study provided a few examples to reveal similarities, differences and potential explanations for Industry 4.0 in an economy with dualistic character, highlighting issues with economic geographical relevance to the semi-peripheral Eastern Hungary. The results point to the fact that the spatial structure outlined over the last decades would not change significantly, the areas that have been thriving are expected to retain their advantage in Hungary and the further concentration of value-producing processes in corporations and around cities is likely. It also has to emphasize that we have to prepare for global processes both nationally and locally, and this requires primarily the renewal of the education system, the development of the Hungarian mediumsized enterprises and the strengthening of the institutional framework for co-operation. Even with these measures, it is questionable whether the country can move forward in the absence of internationally competitive, innovative Hungarian businesses.
There are several options for continuing the research. One of the most important is the extension of empirical studies. This is necessary, on the one hand, because the conclusions based on interviews reflect only those experienced in the case of a few companies, which, however, certainly provided decisive information to Industry 4.0 on processes in a semi-peripheral region. On the other hand, investigations should also be continued to control the primary results and to reveal new connections between Industry 4.0 and the economic geography of companies. Another research direction may be to explore what characterises businesses at a disadvantage as a result of the expansion of Industry 4.0. These all together will enable a more detailed and complete picture of the realisation of Industry 4.0 in Hungary and of its economic geographical context.

Acknowledgements: The research was implemented in the framework of the NKFIH project (project number: K 125091). Authors express their gratitude hereby for the support. The authors thank Norbert Apátı for his assistance in cartographical work.

\section{REFERENCES}

Alcácer, J., Cantwell, J. and Piscitello, L. 2016. Internationalization in the information age: A new era for places, firms, and international business networks? Journal of International Business Studies 47. (5): 499-512.

Arrighi, G. 2014. A fejlődés illúziója. A félperiféria koncepciójának megújítása (The developmentalist illusion. A reconceptualization of the semi-periphery). Eszmélet 26. (103): 159-192.

Autor, D.H. 2015. Why are there still so many jobs? The history and future of workplace automation. Journal of Economic Perspectives 29. (3): 3-30.

BABвiE, E. 2008. A társadalomtudományi kutatás gyakorlata (The practice of social research). Budapest, Balassi Kiadó.

BArta, Gy. 2002. A magyar ipar területi folyamatai 1945-2000 (The territorial processes of the Hungarian industry 1945-2000). Budapest-Pécs, Dialóg Campus Kiadó.

Barta, Gy., Czirfusz, M. and Kukely, Gy. 2008. Újraiparosodás a nagyvilágban és Magyarországon (Reindustrialization in the World and in Hungary). Tér és Társadalom 22. (4): 1-20. 
Brettel, M., Keller, M., Rosenberg, M. and FriederichSEN, N. 2014. How virtualization, decentralisation and network building change the manufacturing landscape: An industry 4.0 perspective. International Journal of Mechanical, Aerospace, Industrial, Mechatronic and Manufacturing Engineering 8. (1): 37-44.

Czél, B. 2019. Magyar családi középvállalatok és az ipar 4.0 lehetóségei (Opportunities of the Hungarian medium-sized family businesses and perspectives of industry 4.0). Master Thesis, Budapest, Corvinus Egyetem.

DESI 2019. A digitális gazdaság és társadalom fejlettségét méró mutató, országjelentés (Indicator of the development of the digital economy and society, country report.) European Commission. Available at https://ec.europa.eu/hungary/news/20190611_ desi2019_hu

Göтz, M. and JAnкоwsкA, B. 2017. Clusters and Industry 4.0 - do they fit together? European Planning Studies 25. (9): 1633-1653.

Józsa, V. 2019. A vállalati beágyazódás útjai Magyarországon (The paths of corporational embedding in Hungary). Budapest, Dialóg Campus Kiadó.

Kagermann, H., Anderl, R., Gausemeier, J., Schuh, G. and WAhlster, W. (eds.) 2016. Industrie 4.0 in a Global Context. Munich, Acatech Study.

KIss, E. 2007. The impacts of relocation on the spatial pattern to Hungarian industry. Geographia Polonica 80. (1): 43-61.

KIss, É. 2010. Területi szerkezetváltás a magyar iparban 1989 után (Regional restructuring in the Hungarian industry after 1989). Budapest-Pécs, Dialóg Campus Kiadó.

KIss, É. (ed.) 2013. A hazai ipari parkok különböző dimenzióban (Hugarian industrial parks in different dimension). Budapest-Pécs, Dialóg Campus Kiadó.

KIss, J. 2003. Az alföldi városok fejlődésének adottságai az 1990-es évek új feltételrendszerében (The capabilities of urban development in the Great Plain of Hungary in the new conditionalities of the 1990s). In Várossiker alföldi nézőpontból. Eds.: TIMÁR, J. and Velkey, G., Békéscsaba-Budapest, MTA RKK ATI - MTA Társadalomkutató Központ, 39-54.

Kopp, J. and BAsL, J. 2017. Study of the readiness of Czech companies to the industry 4.0. Journal of Systems Integration 8. (3): 39-45.

Kovács Sz., Lux, G. and PÁger, B. 2017. A középvállalatok szerepe a feldolgozóiparban: egy magyarországi kutatás első eredményei (The role of medium-sized enterprises in manufacturing: first results of a research in Hungary). Területi Statisztika 57. (1): 52-75.

LASEUR, L. 2019. The Influence of Industry 4.0 on Reshoring. Enschede, NL, University of Twente.

Lengyel, I., Szakálné Kanó, I., VAs, Zs. and Lengyel, B. 2016. Az újraiparosodás térbeli kérdőjelei Magyarországon (The spatial questions of the reindustrialisation in Hungary). Közgazdasági Szemle 63. (6): 615-646.
Lengyel, I. and VArGA, A. 2018. A magyar gazdasági növekedés térbeli korlátai - helyzetkép és alapvető dilemmák (The barriers of the Hungarian economic growth - the situation and fundamental dilemmas). Közgazdasági Szemle 65. (5): 499-556.

LIU, C.L.E. and ZHANG, Y. 2014. Learning process and capability formation in cross-border buyersupplier relationships: A qualitative case study of Taiwanese technological firms. International Business Review 23. (4): 718-730.

Losonci, D., TakÁcs, O. and Demeter, K. 2019. Az ipar 4.0 hatásainak nyomában - a magyarországi jármúipar elemzése (The footsteps of industry 4.0 - an analysis of the Hungarian vehicle industry). Közgazdasági Szemle 52. (2): 185-218.

Lux, G. 2017. Ujraiparosodás Közép-Európában (Reindustrialisation in Central Europe). Budapest-Pécs, Dialóg Campus Kiadó.

Molnár, E. and Lengyel, I.M. 2015. Újraiparosodás és útfüggőség (Reindustrialisation and path dependence). Tér és Társadalom 29. (4): 42-59.

Molnár, E., Kozma, G., Mészáros, M. and Kiss, É. 2020. Upgrading and the geography of the Hungarian automotive industry in the context of the fourth industrial revolution. Hungarian Geographical Bulletin 69. (2): 137-155.

Monostori, L., KádÁr, B., Bauernhansl, T., Kondoh, S., Kumara, S., Reinhart, G., Sauer, O., Schuh, G., SiHN, W. and UEDA, K. 2016. Cyber-physical systems in manufacturing. CIRP Annals 65. (2): 621-641.

Müller, J.M., Buliga, O. and Voigt, K.I. 2018 Fortune favours the prepared: How SMEs approach business model innovations in Industry 4.0. Technological Forecasting and Social Change 132 (1): 2-17.

Nagy, Cs. and MolnáR, E. 2019. Az ipar 4.0 területi összefüggései a robotizáció tükrében: milyen hatásai lehetnek a folyamatnak Magyarországon? (The territorial context of industry 4.0 in the light of robotization: what effects can it have in Hungary?) Területfejlesztés és Innováció 12. (2): 3-18.

NAGY, J. 2017. Az ipar 4.0 fogalma, összetevói és hatása az értékláncra (The concept, and elements of Industry 4.0 and its effects on value chains). Retrieved from http://unipub.lib.uni-corvinus.hu/3115/

Nemes Nagy, J. and Lôcsei, H. 2015. Hosszú távú megyei ipari növekedési pályák (1964-2013) (Long-term county-level industrial growth paths [1964-2013]). Területi Statisztika 55. (2): 100-121.

Nick, G. 2018. Az Ipar 4.0 hazai adaptációjának kihívásai a vállalati és területi összefüggések tükrében (The challenges of adaptation of Industry 4.0 in Hungary in corporate and territorial context). PhD Thesis, Győr, Széchenyi István University.

Nick, G., VÁrgedő, T., NAgy, Cs. and Szaller, Á. 2019. The territorial contexts of industry 4.0 in Hungary, the present and future challenges and expectations of the digital ecosystem. Deturope 11. (3): 29-58. 
Porter, M.E. and Heppelmann, J.E. 2014. How smart, connected products are transforming competition. Harvard Business Review 92. (11): 64-88.

RouhamaA, H., Kantola, J.I. and Salminen, V. 2018. Value network development in Industry 4.0 environment. In Advances in Human Factors, Business Management and Leadership. Eds.: Kantola, J.I., Barath, T. and Nazir, S., Cham, Springer AG. 29-39.

Rüssmann, M., Lorenz, M., Gerbert, P., Waldner, M., Justus, J., Engel, P. and Harnisch, M. 2015. Future of Productivity and Growth in Manufacturing. Boston, MA, Boston Consulting.

Stehrer, R. and Stöllinger, R. 2015. The Central European manufacturing core: what is driving regional production sharing? FIW-Research Reports 2014/15 No. 02.

Strange, R. and Zucchella, A. 2017. Industry 4.0, global value chains and international business. Multinational Business Review 25. (3): 174-184.

Szalavetz, A. 2016. Egy előre bejelentett forradalom krónikája Magyarországon - Ipar 4.0-technológiák és a hazai feldolgozóipari leányvállalatok (Chronicle of a revolution foretold in Hungary
- Industry 4.0 technologies and manufacturing subsidiaries). Külgazdaság 60. (9-10): 28-48.

Szalavetz, A. 2019. Digitalization, automation and upgrading in global value chains - factory economy actors, versus lead companies. Post-Communist Economies 31. (5): 646-670.

Szalavetz, A. and Somosi, S. 2019. Ipar 4.0-technológiák és a magyarországi fejlődés-felzárkózás hajtóerőinek megváltozása - gazdaságpolitikai tanulságok (Impact of industry 4.0 technologies on the engines of development and catch-up in Hungary - some lessons for economic policy). Külgazdaság 63. (3-4): 66-93.

Szanyi, M. 2010. A dualitás kérdése a rendszerváltást követő gazdasági fejlödésben (The problem of duality in the post-socialist economic growth). Competitio 9. (1): 71-90.

Tuahjono, B., Esplugues, C., Ares, E. and Pelaez, G. 2017. What does Industry 4.0 mean to supply chain? Procedia Manufacturing 13. 1175-1182.

Tortorella, G.L. and Fettermann, D. 2018. Implementation of industry 4.0 and lean production in brazilian manufacturing companies. International Journal of Production Research 56. (8): 2975-2987. 